\title{
ENGAGEMENT POLICIES IN FAVOUR OF TRANSNATIONALISM: THE EXPANSION OF TRANSNATIONAL CITIZENSHIP WITHIN COLOMBIAN EMIGRANTS
}

\begin{abstract}
Yolanda González-Rábago ${ }^{1}$
Communities of nationals living abroad are attracting the interest of sending countries, which are paying increasing attention to the way in which emigrants connect with their origin and the potential benefits of it. Focusing on the case of Colombia and analysing the initiatives under the Colombia Nos Une Program, this article examines the role that the proactive attitude of institutional actors is playing in the potential engagement of migrants with their country of origin and the creation of a transnational citizenship. Colombia, as a sending country, is looking at their emigrants in an attempt to take advantage of their economic and human capital in order to improve its development through networks of knowledge, entrepreneurship and socio-cultural initiative. An increasing knowledge of the way policies of origin are implemented and the impact they have on the migrants' lives will give a more comprehensive framework to understand the effects of a transnational life and to conceptualize a transnational citizenship.
\end{abstract}

Keywords: engagement policies, Colombia, emigration, citizenship, transnationalism.

\section{Introduction}

Over the past few years, migrant sending countries have begun to draw attention to the issue of where their emigrants are living and about the role they are playing both in terms of that country's development and how they represent that country on the world stage. Governments of the sending countries are now more aware of their high population numbers which have emigrated and the reasons for such mobility. What is more, these governments are granted new categories of extra-territorial citizenship and they are beginning to examine both the macro and micro consequences of such emigration upon their country.

\footnotetext{
1 University of the Basque Country. Biscay, Spain.
} 
Therefore, emigrant policy initiatives are becoming an increasingly noticeable part of the political landscape around the world ${ }^{2}$.

In this sense, over the last few decades, dual citizenship has also been on the political agenda of many countries around the world. With the exception of few countries with a strict communitarian sense of belonging, most of the countries have accepted or tolerated dual citizenship in some form. This worldwide trend represents a big change in the mainstream understanding of the relationship between citizens and states ${ }^{3}$. As Bauböck ${ }^{4}$ states, while an important body of research has been carried out related to migrants' access to citizenship in the receiving countries, less attention has been devoted to external citizenship rights that migrants enjoy in their countries of origin. During the last decade, however, some authors have highlighted a policy trend on the extension of rights for emigrants and they have conceptualized the transnational citizenship ${ }^{5}$.

Nowadays, sending countries have become aware of the important loss of human and social capital which is caused by emigration. Likewise, there is recognition of the emigrants' value and contribution to the society of origin through remittances and from other kinds of non monetary contributions (social, cultural, knowledge, etc). Therefore, countries of origin are beginning to value the potential resources that emigrating communities may have for the development of their countries and be sensitive to the living conditions of emigrants in the receiving societies. A new concern about the protection of emigrants has been developed by the state, which should have always been an obligation, but has not been a priority until recently. As Cristina Escobar ${ }^{6}$ states, the variations among countries in the timing and forms of the protection, services and extended political rights to their nationals abroad depends on the timing and dimensions of the emigration and the socioeconomic characteristics of the emigrants from each countries. Besides, the progressive recognition and extension of citizenship rights to emigrants in some countries as a state project do not have to underplay the struggles that have taken place in some contexts to obtaining these rights.

At present, the new migration policies are trying to be integral, combining the traditional support of nationals living abroad through Embassies and

2 PADILLA, Beatriz. Engagement Policies and Practices: Expanding the Citizenship of the Brazilian Diaspora; GAMLEN, Alan et alii. Explainig the Rise of Diaspora Institutions.

3 BRØNDSTED SEJERSEN, Tanja. I Vow to Thee My Countries? The Expansion of Dual Citizenship in the 21st Century. International Migration Review, v. 42, n. 3, 2008, p. 523-549; BLATTER, Joachim. Dual Citizenship and Theories of Democracy. Citizenship Studies, v. 15, n. 6-7, 2011, p. 769-798.

4 BAUBÖCK, Rainer (ed.). Migration and Citizenship: Legal Status, Rights and Political Participation.

5 CALDERÓN Leticia (ed.). Votar en la Distancia: La Extensión de derechos políticos a migrantes, experiencias comparadas; MORAES, Natalia et alii. Las Dinámicas de Vinculación Transnacional de los Estados Latinoamericanos y sus Diásporas, 2008; LAFLEUR, Jean-Michel. Why do States Enfranchise Citizens Abroad? Comparative Insights from Mexico, Italy and Belgium; GAMLEN, Alan. Creating and Destroying Diaspora Strategies. University of Oxford: International Migration Institute, 2011; GAMLEN, op. cit.; PADILLA, op. cit.

6 ESCOBAR, Cristina. Dual citizenship and extraterritorial political rights in Latin America, p. 44. 
Consulates with an extension of citizenship rights, as well as an awareness raising policy about the emigration process for those who have not yet emigrated. In addition, something is changing about addressing the demands of the emigrant populations, such as voting rights, access to social services from abroad (health services, retirement pensions, etc.), and a better recognition of diplomas and cultural or political issues in the receiving countries.

Within this intention to provide attention, support and protection for non-resident citizens, there is also an opportunity to know more about where and how they are living and their relationship with the countries of origin. In this way, this is a chance to control the diasporas in order to take advantage of their potential resources and social capital in favour of the interests of the sending country. In this article I underline the importance of knowing what types of policies states are adopting, and their reasons for doing so. For this purpose, we will analyse the case of Colombia paying special attention to symbolic and extension policies, as an example of the new attitude of states towards fellow members which is creating an emigrants' citizenship in the transnational space.

\section{Transnational implications of engagement policies}

New emigration policies within the countries of origin are trying to generate and strengthen a sense of belonging and an image of the nation beyond the state boundaries which involve the population overseas ${ }^{7}$. The transnational strategies of the national state, however, do not overcome the limitations of the methodological nationalism approach ${ }^{8}$. On the contrary, promotion of the transnational attitudes in nationals living abroad is a new form of methodological nationalism in terms of the way the community is imagined. Home countries are willing to build a transnational citizenship within nationals living abroad, in an attempt to produce the imagined community, defined by Benedict Anderson: "It is imagined because the members of even the smallest nation will never know most of their fellow-members, meet them, or even hear of them, yet in the minds of each lives the image of their communion" ${ }^{\prime \prime}$.

Accordingly, the state lives not only inside the national geography, but also in all those emigrants who are supposed to be committed to the nation. Policies are redefining the relationship between the state and its territorial boundaries and

LEVITT, Peggy, DE LA DEHESA, Rafael. Transnational Migration and the Redefinition of the State: Variations and Explanations; GAMLEN, Alan. Diaspora Engagement Policies: What are they, and what Kind of States use them?

8 WIMMER, Andreas, GLICK SCHILLER, Nina. Methodological Nationalism, the Social Sciences and the Study of Migration: An Essay in Historical Epistemology. International Migration Review, v. 37, n. 3, 2003, p. 576-610; AMELINA, Anna et alii. Beyond Methodological Nationalism. Research Methodologies for Cross-Border Studies.

9 ANDERSON, Benedict. Comunidades Imaginadas: Reflexiones Sobre El Origen Y La Difusión Del Nacionalismo, p. 96. 
to some extent, reconfiguring understandings of citizenship and membership ${ }^{10}$. Some important countries of origin are putting into practice proactive engagement policies and are trying to reinvent themselves as countries that support migrant connections within the diverse spheres of the economic, social, political and cultural life of that country.

The increasingly active role of the state in maintaining a long-distance membership with the emigrated population is a significant indicator that the transnational perspective is progressively consolidating in order to study citizenship. Transnational dynamics are becoming so important that institutional actors are creating the best political conditions to keep emigrants as active citizens. States can play a major role in creating and reproducing transnational involvements and, in this context, a growing number of origin states have established formal diaspora institutions, which can be found in more than half member states of United Nations, as well as legal reforms to facilitate external citizenship ${ }^{11}$.

However, there is some discussion in the scientific community about how these policies are supporting forms of transnational engagement but not necessarily of citizenship ${ }^{12}$. Is the extension of formal rights to emigrants enough to promote an active citizenship from abroad? Are these engagement policies creating a more intense relationship between emigrants and the country of origin? Although there is no consensus about this phenomenon, some evidences, especially in Latin America, show the configuration of a transnational citizenship, not only in relation to how states consider their nationals abroad but also with reference to the way emigrants are able to take part in the political and social life of their countries of origin.

A number of scholars have proposed different ways to analyse the engagement policies and the transnational practices (see Table 1) ${ }^{13}$. Of particular interest are Goldring's classification, which makes a distinction between policies of introversion and policies of extension, and the typology proposed by Levitt and De la Dehesa, who suggest studying these policies from the perspective of the changes, reforms and measures introduced under this paradigm, distinguishing between: ministerial or consular reforms; investment policies to channel migrant remittances; extension of political rights, such as dual citizenship or the right to

\footnotetext{
${ }^{10}$ LEVITT, DE LA DEHESA, op. cit.

${ }^{11}$ GAMLEN et alii, op. cit.

${ }^{12}$ FOX, Jonathan. Unpacking Transnational Citizenship. Annual Review of Political Science, v. 8, n. 1, 2005, p. 171-201.

${ }^{13}$ GOLDRING, Luin. The Power of Status in Transnational Social Spaces. In Transnationalism from Below Comparative Urban and Community Research, edited by Luis Eduardo GUARNIZO and SMITH. Michael, New Jersey: Transaction Press, 1998, p. 165-195; LEVITT, DE LA DEHESA, op. cit.; ITZIGSOHN, Jose. Immigration and the Boundaries of Citizenship: The Institutions of Immigrants' Political Transnationalism. International Migration Review, v. 34, n. 4, 2000, p. 11261155; OSTERGAARD-NIELSEN, Eva, The Politics of Migrants' Transnational Political Practices; GUARNIZO, Luis Eduardo et alii. Assimilation and Transnationalism: Determinants of Transnational Political Action among Contemporary Immigrants; GAMLEN, op. cit.
} 
vote from overseas; extension of state protection and services to nationals living abroad beyond consular services; and symbolic politics to reinforce emigrants' sense of belonging. The final model I would like to mention is that of Padilla ${ }^{14}$, who distinguished between: institutional reforms (executive and legislative); investment policies and levy of duties aimed at managing migrant remittances and reinforcing emigrants' investment and trade; extension of rights (the right to vote, recognition of diplomas completed abroad); symbolic policies publicising the country and its economic, social and cultural potential; international relations, signing bilateral or multilateral agreements and applying reciprocal punishment actions; and partnerships with civil society (NGOs at origin and destination, knowledge networks or immigrant organizations).

Table 1 - Models of engagement policies and transnational practices

\begin{tabular}{|l|l|}
\hline Authors & Principal characteristics \\
\hline Goldring (1998) & $\begin{array}{l}\text { a) Policies of introversion (protection to sojourners), b) Policies } \\
\text { of extension (protection to settled diasporic communities) }\end{array}$ \\
\hline Itzigsohn (2000) & $\begin{array}{l}\text { Actors in transnational politics: a) The state apparatus of the } \\
\text { country of origin, b) The political parties of the country of } \\
\text { origin, c) Migrant organizations in the country of reception }\end{array}$ \\
\hline $\begin{array}{l}\text { Ostergaard-Nielsen } \\
\text { (2003) }\end{array}$ & $\begin{array}{l}\text { Political transnational practices: a) Immigrant politics, b) } \\
\text { Homeland politics, c) Emigrant politics, d) Diaspora politics, e) } \\
\text { Trans-local politics }\end{array}$ \\
\hline Levitt and De la & $\begin{array}{l}\text { a) Bureaucratic reforms, b) Attracting investment policies c) } \\
\text { Extension of political rights, d) Extension of state services } \\
\text { abroad, e) Symbolic politics to reinforce the national identity. }\end{array}$ \\
\hline Gamlen (2003) & $\begin{array}{l}\text { a) Capacity building policies, b) Extending rights, c) Extracting } \\
\text { obligations }\end{array}$ \\
\hline Padilla (2011) & $\begin{array}{l}\text { a) Institutional reforms, b) investments policies and duties } \\
\text { extraction, c) extension of rights, d) symbolic policies, e) } \\
\text { international relations, f) partnerships with civic society }\end{array}$ \\
\hline
\end{tabular}

Source: Adapted from Padilla and Ortiz (2012).

All those engagement policies suggest the use of the concept transnational citizenship, which can better describe the new characteristics of the exercise of an emigrant's citizenship in transnational spaces ${ }^{15}$. As defined by Bauböck ${ }^{16}$, transnational citizenship refers to a dual process: on the one hand, increasing political action on the part of migrants with regard to their home countries and, on the other hand, a progressive institutional change in both the country of origin and the destination country.

\footnotetext{
${ }^{14}$ PADILLA, op. cit.

15 PADILLA, Beatriz; ORTíz, Alejandra. Ciudadanía Transnacional de Latinoamericanos en Portugal: Considerando el País de Origen y de Destino, p. 15.

${ }^{16}$ BAUBÖCK, op. cit.
} 


\subsection{Creating transnational citizenship as a global trend}

A number of important sending countries in different regions of the world are developing migration policies and legal reforms which are aimed at increasing the relation between the emigrants and their country of origin, in other words, policies that are in favour of transnationalism. Giving people the opportunity to be non-residential citizens with almost every right is the first step towards engaging the nationals living abroad in the social and economic life of the origin country. The next step consists of launching programs of social protection and investment benefits. Sending countries are trying to give to emigrant communities political rights in exchange for economic and social resources. The policies aimed at strengthening emigrants' ties with their home country follow a number of different stages, with what appears to be a smooth transition from one to the next.

Recently, major sending countries, but also smaller ones, have carried out constitutional reforms as well as launching re-link programs. A significant example of this is the Ecuadorian migration policy, which began promoting state relationships with emigrants in 1998, when the Constitution recognized the right to vote to Ecuadorians living abroad. A qualitative leap was made in 2008 when the new Constitution created a special electoral district in the Congress with six congressmen to represent Ecuadorian emigrants. This Constitution recognizes the immigrant community as an essential political subject and as a result, a comprehensive migration policy was created for that purpose ${ }^{17}$. In 2009 the government launched the SENAMI (National Secretary of Migrants, for its acronym in Spanish) which developed and implemented a large number of programs, projects and measures aimed at strengthening relations between emigrants and their country of origin, not only in the economic sphere but also in the social, cultural and political one ${ }^{18}$.

Another country that has been active in developing transnational state policies is Mexico. In order to address the large number of Mexican emigrants living in the United States, whose remittances are significant for the economy of their home towns, the Mexican government, has joined with Hometown Associations of emigrants living in United States in what is known as the $3 \times 1$ Program. The commitment of the government to the country's development is supported by the idea that emigrants can play an important role in their place of origin ${ }^{19}$.

Engagement and transnational policies are also significant in developed countries such as Italy, New Zealand or Belgium ${ }^{20}$. Their policies, however, are

\footnotetext{
${ }^{17}$ CORTÉS, Almudena. The Transnational Governance of Ecuadorian Migration through Co-Development.

${ }^{18}$ BOCCAGNI, Paolo. Reminiscences, Patriotism, Participation: Approaching External Voting in Ecuadorian Immigration to Italy.

${ }^{19}$ LAFLEUR, op. cit.; GARCÍA ZAMORA, Rodolfo. El Programa Tres Por Uno De Remesas Colectivas En México. Lecciones Y Desafíos. Migraciones Internacionales, v. 4, n. 1, 2007, p. 165-172.

${ }^{20}$ LAFLEUR, op. cit.; GAMLEN, op. cit.; SMITH, Robert C. Diasporic Memberships in Historical Perspective: Comparative Insights from the Mexican, Italian and Polish Cases.
} 
more restricted to political rights such as external voting and dual citizenship, instead of symbolic initiatives or extraction of obligations. Otherwise, other countries in Latin-America have developed similar re-link policies, the most common of which are related to the productive remittances, return programs, creation of a knowledge networks and recognition of political rights. Countries such as Uruguay, Argentina or Brazil are putting into practise engagement policies that seek to recover a sense of national belonging, in an attempt to promote and take advantage of resources and power of emigrants ${ }^{21}$.

All these policies create an increasing a sense of belonging beyond borders and a transnational citizenship which can be practiced thanks to the progressive formation of transnational spaces. Institutional actors as well as civil society are building the conditions for an easier relation with the diaspora. More and more governments are seeing the configuration of transnational spaces as an opportunity to recover the commitment and the power of nationals living abroad. Thus, this process breaks with the traditional understanding of the citizenship and changes the relationship between state and citizens ${ }^{22}$. The creation of a transnational citizenship is becoming a way to manage the consequences of international mobility.

\section{The case of Colombia}

A brief overview of the different stages in Colombia's migration history will enable us to gain a better understanding of the engagement policies for the Colombian diaspora. Colombia is not only a country from which large numbers of people emigrate, but also a country that receives immigrants from neighbouring countries (Ecuador, Peru or Bolivia). The migration situation in Colombia today has played an important role in shaping the new transnational policies that are analysed below.

Despite innumerable attempts on the part of the government and academia to estimate the volume of the emigrant population and to compare different sources of information, there is no consensus and there is a visible discordance between different sources. According to the National Census of 2005 Colombia has 3,332,107 fellow-members living overseas, which represents more than $8 \%$ of its total population. However, the task of measuring the quantity and the destination of Colombian emigrants is not an easy task. The cumulative data collected by the World Bank ${ }^{23}$ from 210 countries estimate that 2,122,100 Colombians are living abroad. A recent study in Colombia ${ }^{24}$ which has gathered

\footnotetext{
${ }^{21}$ MORAES et alii, op. cit.; LAFLEUR, Jean-Michel. The Transnational Political Participation of Latin American and Caribbean Migrants Residing in Europe

22 BAUBÖCK, op. cit.

${ }^{23}$ WORLD BANK. Migration and Remittances Factbook 2nd Edition. Washington DC: The International Bank for Reconstruction and Development. 2011.

${ }^{24}$ MEJ́́A, William. Colombia y Las Migraciones Internacionales. Evolución Reciente y Panorama Actual a Partir De Las Cifras.
} 
information from 58 principal destination countries, primarily through census data of 2010, has concluded about 2,119,149 are living abroad. Taking into account an uncollected percentage of $15 \%$ (hidden irregular immigration) and $10 \%$ of people living in countries other than the 58 countries studied, the total amount could be 2,700,000.

In this context, at the beginning of the 2000s, the Colombian state became aware of the emigration situation, and it was recognized that the situation was structural, non circumstantial. As a result of this, the government began to plan a more effective protection of the Colombian community abroad. Within the Development National Plan 2003-2006, the idea of an integral policy regarding the emigrant population was included. The Colombian community living abroad became an object of public policy with a view to stimulating their links with their home country. The government launched Colombia Nos Une Program in 2003, which is still operative today.

Moreover, the upheaval political scenario and the intense violence situation of Colombia during the 1990s had an effect not only in the increase of the international emigration but also in a distant relationship of emigrants with the state. Therefore, the new emigration policy of Colombia in the 2000s aimed at engaging this population with the state and tried to de-politicize the historical bases of emigration.

In this article we will focus on two types of engagement policies aimed at ensuring that emigrants maintain enduring long-distance memberships of the home community: symbolic and extension policies. However, before analysing these policies, it is important to highlight the fact that strengthening the membership of the diaspora is also important from a bureaucratic and normative perspective of citizenship. As was explained before, political rights such as dual citizenship, external voting, or even, the development of parliamentary representation for emigrated communities, represents the first step towards engaging them.

\subsection{Legislative initiatives and other emigration policies}

During the last decade of the $20^{\text {th }}$ century, Colombia implemented legislation related to emigrants in various ways. In 1991, the Colombian parliament approved dual citizenship for those who want to naturalise to a country which permits dual membership. As in other countries, the recent development of dual citizenship within the wider framework of diasporic policies allows for continuity of belonging without denying the option to become a full member of the host society in which the emigrant wants to integrate. Although external voting has been permitted since 1958, dual citizenship is a step forward towards a full consideration of nationals abroad. "The status of emigrants living outside the national territory is 
now seen as compatible with polity membership ${ }^{\prime 25}$. Moreover, a parliamentary representation of Colombians residing abroad was created in 1976, although it was not implemented until the presidential election of 2002. The article 176 of the Constitution that allows the representation of the community of emigrants has suffered many changes after years of reforms, not because of any opposition to the non-resident franchise but because of the complexity of the article ${ }^{26}$.

Beyond giving political rights for the participation of emigrants in the internal political landscape, Colombia has also developed a number of initiatives focusing on providing them with protection and services in the transnational sphere. To this end, the Colombian state has signed bilateral agreements with principal destination countries, such as Social Security Agreements, circular migration quotas, or voting in local elections. All those improvements in the status of emigrants reinforce their engagement with their country and foster a wider transnational relationship.

The extension of citizenship rights to non-residents is important not only from the sending country's perspective, but also from the point of view of citizenship in the receiving state, since engagement polices may be an important determinant for immigrant choices between full involvement in destination country, returning to the country of origin or a transnational way of living ${ }^{27}$.

\subsection{Colombia Nos Une Program}

The Colombia Nos Une Program (CNU) was born in 2003 and was based on the assumption of the existence of transnational relations within Colombian communities. This Program began its activity with the aim of increasing and strengthening the links of the state with the Colombian communities overseas, recognizing them as an essential part of the Colombian nation and, therefore, taking them into account as a priority in the public policy. Likewise CNU highlights the great opportunity this offers to create a constructive link with the scientific, academic and intellectual community abroad, through the formation of entrepreneurship, cultural and cooperation networks. In this sense, a strategic investment was the virtual site named RedEsColombia, which serves as an information and communication network aimed at making it easier for Colombians abroad to keep in contact with their home country. RedEsColombia aims to be an open space for every Colombian who wants to establish any kind of link with other Colombians, institutions inside and outside the country (universities, enterprises or any kind of associations and organizations) or the state.

What is particularly interesting about Colombia Nos Une is its focus on highly skilled emigrants (brain circulation), and the idea of incorporating emigrants'

\footnotetext{
${ }^{25}$ LAFLEUR, Why do States..., op.cit. p. 482.

${ }^{26}$ ESCOBAR, op. cit.

27 BAUBÖCK, op. cit. p. 27.
} 
"talent". Whereas other countries have tried to leverage collective remittances for community projects and investor remittances for business development, perhaps more symbolically than practically, the Colombian case is quite focused on drawing in talent without necessarily repatriating people.

The fundamental question to address now is why such active policies of linkage are being promoted at this particular moment in Colombian migration history. In other words, why the CNU now? There are a number of factors, which are more or less evident and explicitly shown through the political discourse. On the one hand, the state is more conscious of the problems related to the mobility of a five million people, as is the case with Colombia, and, on the other hand, the increasing attention neighbour states are giving to diasporas demonstrates an increase in the awareness of the emigrant situation and the desirability of extending citizenship rights.

Nevertheless, there are other factors which are not openly shown or are even deliberately concealed, but in fact constitute the most important reasons for aiming to promote transnational communities. These elements relate to the phase of migration that the home country is passing through or, more precisely, the phase of integration that Colombians abroad are living through. In other words, Colombian emigrants today who left the country during the last migration phase, at the end of the nineteen nineties and at the beginning of the 2000's, are experiencing a semi-permanent settlement process in host societies.

Although the integration process of migrants has been important in other periods of history, the significant volume and characteristics of the population who emigrated during the latest period is incomparable. It has created an awareness of the effects within the social and family sphere, but also in the economic, cultural and political area where the state is trying both to minimize the negative consequences and also to maximize the positive feedback.

According to the estimates of the International Organization for Migration ${ }^{28}$, thousands of Colombians living abroad have a high level of skills and qualifications. In the year 2000, Colombia was the Latin American county with the greatest number of professional emigrants in the United States and the percentage of highly skilled professionals from Colombia ${ }^{29}$. Similarly, it was found that the proportion of highly skilled people who return to their home country is lower than those who are less qualified. Therefore, the Colombian state is

\footnotetext{
${ }^{28}$ International Organization for Migration. Perfil Migratorio de Colombia 2010. V. 2013. Bogotá: IOM, 2010.

${ }^{29}$ DOCQUIER, Fréderic, MARFOUK, Abdeslam. International Migration by Educational Attainment (1990-2000). In ÖZDEN, Cagglar; SCHIFF, Maurice. International Migration, Remittances and the Drain. Chapter 5: Palgrave-Macmillan, 2006; MEDINA, Carlos, POSSO, Camilo. Colombian and South American Immigrants in the United States of America: Education Levels, Job Cualifications and the Decisión of Go Back Home.
} 
now very aware of the brain drain that occurred during the latest stage of the emigration history of Colombia.

In addition, there is a considerable amount of research being carried out today about the migration process, focussing on how a successful integration process can be achieved for immigrant populations. Some research projects in the US case in relation to different national communities (Colombian, Dominicans and Mexicans) have concluded that the more integrated in the host society immigrants are, the more prone they are to participate in transnational activities ${ }^{30}$. All these causes are more than enough to induce governments to make policies in order to maintain and foster links among the expatriates. Sending countries need to retain the loyalty of their emigrants and also to promote activities such as remittances and investments, which are at risk due to the semi-permanent nature of settlement and effective integration into the host societies, which can break the personal commitment to the home country.

\section{Strategies for involving emigrants with Colombian development: the promotion of a national sense of belonging at a distance}

'Strengthening ties with Colombians abroad' is the slogan of the Colombia Nos Une Program, and the actions which were carried out focus upon this core idea. Using text and visual analysis, five types of strategies have been identified: Human Capital and Knowledge Networks; Trade and Economic Investments; Culture and Values; Community and Sense of Belonging; and Political Promotion. The strategies have been distinguished through a wide range of actions and awareness campaigns which were launched by the Colombian government between 2011 and 2013. These activities or programs were addressed to diverse groups of Colombian emigrants and with different aims. Table 2 lists those actions or programs considered for the analysis.

\subsection{Human Capital and Knowledge Networks}

The analysis has revealed three main types of actions which are related to three aims of Colombian policy to re-gain the drain in human capital, which occurred as a consequence of emigration over the last few decades. As was explained before, the high-skill emigration of Colombians represents an important proportion of the nationals living abroad, and the brain drain is one of the government's concerns.

\footnotetext{
${ }_{30}$ PORTES, Alejandro et alii. Transnational Entrepreneurs: An Alternative Form of Immigrant Adaptation; PORTES, Alejandro et alii. Immigrant Transnational Organizations and Development: A Comparative Study.
} 
Table 2 - Symbolic and extension activities taken into account for the analysis of Colombian engagement policies

\begin{tabular}{|c|c|}
\hline Strategies and programs & Activities \\
\hline $\begin{array}{l}\text { Human Capital and Knowledge } \\
\text { Networks } \\
\text { Productive Return Program } \\
\text { Academic training for Colombians } \\
\text { abroad } \\
\text { Knowledge Networks in the Distance }\end{array}$ & $\begin{array}{l}\text { Leadership skills - New York - Madrid } \\
\text { Training in the distance - University EAN } \\
\text { Financial training - How to create a business - Entrepreneurship } \\
\text { Support } \\
\text { Network C } \\
\text { Bibliographic Heritage: the footprint of Colombians abroad } \\
\text { Research projects with Colombian universities } \\
\text { Prominent Colombians Project }\end{array}$ \\
\hline $\begin{array}{l}\text { Trade and Economic Investment } \\
\text { Private Investment } \\
\text { Business services for migrants }\end{array}$ & $\begin{array}{l}\text { Housing Counseling: forum, TV program, Real-Estate Exhibitions } \\
\text { Voluntary Savings Account (credit) } \\
\text { Come Back Network } \\
\text { Colombian insurance abroad }\end{array}$ \\
\hline $\begin{array}{l}\text { Culture and Values } \\
\text { Second generation } \\
\text { Colombion Culture and History } \\
\text { Promotion }\end{array}$ & $\begin{array}{l}\text { Colombian Values } \\
\text { Rafael Pombo Foundation } \\
\text { Young FotogrArtits } \\
\text { Special Promotion Programs } \\
\text { Colombian Footprint Abroad } \\
\text { Colombia in an image }\end{array}$ \\
\hline $\begin{array}{l}\text { Community and Sense of Belonging } \\
\text { Migration experience as an example } \\
\text { Celebrations from abroad }\end{array}$ & $\begin{array}{l}\text { Successful experiences of emigrants } \\
\text { Academic and artistic leading figures abroad } \\
\text { Independence Day } 20^{\text {th }} \text { of July } \\
\text { Christmas activities ('This Christmas, get closet o your family, your } \\
\text { friends and your country') } \\
\text { Mother's Day (Encourage the role of the mothers as ambassadors of } \\
\text { Colombia) }\end{array}$ \\
\hline $\begin{array}{l}\text { Political and Organizational Promotion } \\
\text { Consular Services } \\
\text { Migrant associations }\end{array}$ & $\begin{array}{l}\text { Consular Mobile Units } \\
\text { Consular Services Exhibitions } \\
\text { Extension of general services to the emigrant population - } \\
\text { ColPensiones } \\
\text { Promotion of migrant organization in host countries }\end{array}$ \\
\hline
\end{tabular}

Source: Own elaboration.

Therefore, one of the core concerns of the Colombian Migration Policy is to look for ways to bring together the talent and professional skills of Colombian emigrants in order to improve the scientific development of the country, and, moreover, to attract financial investments from these qualified migrants. To this end, three kinds of action have been identified: Return, Training of Colombians living abroad and Academic Distance Networks.

Firstly, the emphasis on encouraging emigrants to return to their home country is clearly seen in the 'Productive Return Program', which has been put into practice through the Colombian Consulate in Spain, offering training in business and management to Colombians living in Spain. The goal of this program is to promote the productive return of capable Colombians who want to start a business or begin a productive project in Colombia to earn their living. Presenting a positive image of the connection in both directions between Spain and Colombia, the 'Productive Return Program' gives an institutional positive 
meaning to the idea of returning, in order to promote at an institutional level a process that is usually considered to be individual.

Secondly, the role of the country of origin in improving the human capital of Colombians has been also developed among the emigrants who have no intention of returning. With the support of other public sector institutions, such as Universidad EAN or Bancolombia, CNU offers to Colombians living abroad opportunities to improve their financial skills or to learn how to become a small entrepreneur. For instance, the Consulates of New York and Madrid held courses in Leadership Skills; Bancolombia was part of a project to improve the financial training of emigrants and their families abroad through teaching ways to save money, how to use a personal bank account, or showing the best channels to send remittances. Apart from this kind of financial training, to help bridge the distance other kinds of educational services are provided. For instance, the Universidad EAN, thanks to a collaboration agreement with CNU and the support of IOM, offers special academic training for emigrants living abroad.

And finally, with the aim of reversing the brain drain, $\mathrm{CNU}$ has developed a strategy to engage academic and scientific professionals who are living around the world. Highlighting the sense of national belonging, $\mathrm{CNU}$ is investing in creating a database of qualified Colombians living abroad, promoting networks and giving support to encourage these emigrants to generate research projects with Colombian Universities or Research Centers. One of these initiatives is " $\mathrm{C}$ Network" in collaboration with the Institut de Recherche pour le Développement (IRD) from France and IOM. From this perspective, other initiatives such as 'Prominent Colombian Abroad' or 'Bibliographic Heritage: the footprint of Colombians abroad', are seeking to regain the scientific knowledge of Colombians, for example, through conferences and academic events.

\subsection{Trade and Economic Investments}

$\mathrm{CNU}$ is promoting private investments by emigrants in order to improve the development of the country. The aim is to move the sense of responsibility for the economic and human development onto the Colombian people living abroad. The government is looking for emigrants to become aware of the economic situation of their country and the important role that they should play in the economic development of Colombia.

On the one hand, CNU has launched awareness campaigns in relation to opportunities for investing in housing, for instance, giving advice about how to buy a house in Colombia during some TV programs and in forums on the official webpage. This is in addition to supporting Real-Estate Exhibitions in many host countries which have been recognized as a great success. In this sense, the promotion of the program "Voluntary Savings Account" among the Colombians 
abroad is trying to develop a culture of saving which allows investment in housing for the future. In addition, this specific program makes it easier to access credit in order to buy a house or to pay for education in Colombia.

$\mathrm{CNU}$ is also supporting the creation of commercial services directed exclusively at emigrants. The significant amount of people who are living abroad is a target population for commercial purposes, especially as they and their families have greater purchasing power. One of most popular services is related to repatriation of corpses and funeral assistance, which is called "Come Back Network". The program was encouraged by the government and different companies specialising in this business, under the slogan "Think about your return, don't stay far from home" (Table 2).

\subsection{Culture and Values}

A third core feature of the Colombian engagement policy is the fostering of Colombian Culture and Values not only among emigrants of first generation people who live abroad, but also among young people and children, most of them second generation who live in the receiving countries. The first kind of action identified under this theme is related to the development of Colombian Culture and History in order to spread the image of a great country among those who are living far away from the home nation. An example of this is the 'Special Promotion Programs' which are defined as activities that focuses on cultural, artistic, sportive and training activities to benefit the co-nationals living abroad. The aim is to preserve and consolidate the national identity through the exaltation of historic, cultural and social values. These activities, which are carried out by the Consulates of Colombia in the principal destination countries, have become more and more important to the Consulate's agenda over the last few years.

Joining arts and culture, the program 'Colombian Footprint Abroad', was set up and launched in 2011 by CNU and Colombia es Pasión in order to look for fingerprints of 25,000 emigrants who live and work in almost 25 cities around Europe, and North and South America. The objective was to generate a sense of belonging and to join the emigrants through art. The main slogan was 'Our Flag, Our Country, Our Home', a reflection of the intention of CNU to strengthen the Colombian Community beyond the national boundaries. These are only some examples of the efforts made by the government to promote their Culture and Values. However, the target population is not only adults in their role as a decision maker, but also their children who were mostly born in the receiving countries, and their knowledge and interest about Colombia are therefore weaker and more uncertain. An intense promotion of Colombia is now taking place between those who are the second generation of emigrants, as a strategy to generate a sense of belonging in these children but also within their parents. An example 
of this is the campaign 'Colombian Values $20^{\text {th }}$ of July', a picture competition aimed at teenagers between 13 and 17 years old. A similar case is the 1st Photography Training 'Young FotogrArtists 2012' aimed to Colombians between 14 and 19 years old living in London, in which teenagers could learn the basics of photography, with a view to creating a photo exhibition focusing on the culture of young Colombian people living in London, providing an opportunity for young people living far away from Colombia to connect with the culture of their roots.

\subsection{Community and Sense of Belonging}

The activities behind this core feature of the policy are the greatest and most visible. They focus on the desire to create a sense of belonging for the Colombian community by means of fostering national pride. There are two kinds of actions, on the one hand, presenting successful migration experiences, either common people in many different countries around the world, or scientific and artistic professionals who have developed their careers abroad. And on the other hand, some specific campaigns launched with reference to some special celebrations, such as the Independence Day 20th of July, Christmas or the Mothers'Day (Table 2).

In the first kind of activities, the CNU Program has two main goals aimed at different audiences. Firstly, CNU tries to show to the population living in Colombia a sample of emigrants who have had a good experience during their migration process. Behind these actions, there is an assumption of the positive impact that emigration has on the lives of people who live abroad and, what is more, a potential positive effect on the country. In some sense, it is an invitation to migrate for those who are thinking about this possibility. The second audience of these activities is the emigrant population itself, whose migration process may not have been as successful as it is represented in the stories chosen by $\mathrm{CNU}$, therefore seeking to show them an example which they can follow in their migration and integration process in the receiving societies. This intention is reflected as well by highlighting the role of experienced emigrants in helping other new Colombians who have just arrived, most of them through Colombian immigrant associations.

In order to show successful migration experiences, by both common people and scientific or artistic professionals, CNU has created a space called 'Prominent Colombians Abroad'. This space aims to illustrate the human capital and the positive role that these people play during their migration process in order to improve the image of Colombia around the world.

Secondly, another way to generate a sense of belonging and national pride among those who are living abroad is the celebration of special festival days in Colombia, specifically Independence Day, Christmas and Mother's Day. Every year some unique activities are organized which invite emigrants to celebrate the 
Independence of Colombia on the 20th of July. A message from the President of the Republic is broadcast exclusively to the emigrant community. This message focuses on the the role that Colombians living abroad plays within the world and the extent to which it is a positive asset for the country. Furthermore, it focuses upon their responsibility to continue contributing to the development of their country even though they are living abroad. It is a reminder of their national pride and its main goal is to promote the continuity of a sense of belonging with repeated messages of your country, your nation and your home. Other similar activities are prepared for Christmas time and the Mothers' Day (Table 2).

\subsection{Political and Organizational Promotion}

Finally, it should be pointed out that the $\mathrm{CNU}$ has some political interests which pursue the improvement of the governmental image among those who have emigrated. The aim is to change somehow the bad opinions of the vast majority of the emigrants regarding politics and politicians in their countries of origin. The $\mathrm{CNU}$ follows a strategy of highlighting the good values of the country and the increasing number of services that are aimed at nationals who live abroad. In an attempt to underpin links with the emigrated population, the national government has recently intensified the presence and services offered by Consulates, publicising their activity and support through Consular Services Exhibitions and Consular Mobile Units in those cities where demand is found. The extension of the policies to the emigrant population is clearly observed via services such as ColPensiones, a public organisation for retirement pensions that it is now also available for emigrants.

Finally, we should point out the significant contribution of the organizational promotion and governmental actions implemented in support of migrant associations or ONG's that are working on the link between migration and development. This is the case of some presentations of different organizations which provide information and present their projects and main activities.

\section{Conclusions}

This article has analysed the Colombian case in order to give empirical evidence of a growing phenomenon around the world regarding the way in which governments are developing policies to actively engage transnational diaspora as active national citizens. Colombia represents a case of particular interest of a global trend in how sending countries are building a transnational citizenship with those nationals living beyond the borders.

Transnational activities and the linkage with origin countries have traditionally been seen as an initiative taken personally by an individual, which have been affected by personal and family situations, but not especially 
influenced by institutional actors. During recent years, however, sending countries have begun to think about how to improve and take advantage of the potential benefit that transnationalism may have for development at home. In this sense, I suggest that the discourse of origin states regarding the attention, protection and promotion provided to transnational communities and of fellow-members overseas is influenced by the migration history of these states. The new policies in this field are determined by the verification of a migratory reality which has evolved towards a more permanent settlement of the population in destination countries.

The analysis of the principal strategies and actions carried out by the Colombian state demonstrates its commitment to taking advantage of the emigrants as valuable resources. Colombians abroad are seen as development facilitators that are able to contribute economically, socially and culturally despite the distance. Above all, some origin countries, like Colombia, are seeking to recover the contact with those emigrants who are highly skilled and those who have a well-off position in host societies. However, sending countries are not only focusing on qualified and prosperous emigrants, but also taking into account the vast majority of the population who are able to contribute to their origin country through economic remittances. As stated previously, Colombia and other sending countries are now at a key moment regarding the maintenance of links between emigrants and their country. The Colombian state is focusing on promoting a broader sense of belonging which allows a simultaneous integration - in both the host country and the country of origin ${ }^{31}$. They are working on building and strengthening a community beyond the borders of the national state and a transnational citizenship which allows migrants to participate and play an active role in their countries. In some way, sending countries are redefining what it means to be a citizen, adapting their conception of citizenship to the modern practice of it.

Does this kind of engagement policy have an effect on the continuity of the emigrants' links? To what extent is this political strategy effective in achieving its goal? Is it possible to measure how much these policies are influencing the behaviours and feelings of the emigrants? These key questions are now on the stage and, as was shown, in the Colombian case, policy analysis can give us some clues as to how states are taking into account the opportunities offered by their diasporas. Especially relevant is the focus on high-skilled emigrants made by the Colombian state, which offers a contrast to state policies in Central American countries and Mexico. Generally, migration and transnational citizenship policies

31 PORTES, Alejandro. Conclusion: Theoretical Convergencies and Empirical Evidence in the Study of Immigrant Transnationalism. International Migration Review, v. 37, n. 3, 2003, p. 874-892; LEVITT, Peggy, GLICK SCHILLER, Nina. Conceptualizing Simultaneity: A Transnational Social Field Perspective on Society. 
in sending countries are changing to a more extensive and intensive attention to and promotion of the emigrant membership compared with the traditional consular efforts. This policy represents a big change in the point of view of the states of origin in relation to their institutional role in the management of the emigration process. The analysis of Colombian migration policy has sought to look at how institutional structures might support and endorse the construction of such a transnational citizenship.

\section{References}

AMELINA, Anna; NERGIZ, Devrimsel; FAIST, Thomas; GLICK SCHILLER, Nina. Beyond Methodological Nationalism. Research Methodologies for Cross-Border Studies. New York: Routlegde, 2012.

ANDERSON, Benedict. Comunidades Imaginadas: Reflexiones sobre el Origen y la Difusión del Nacionalismo. México: Fondo de Cultura Económica, 1993.

BAUBÖCK, Rainer (ed.). Migration and Citizenship: Legal Status, Rights and Political Participation. IMISCOE Reports ed. Amsterdam: Amsterdam University Press, 2006.

BOCCAGNI, Paolo. Reminiscences, Patriotism, Participation: Approaching External Voting in Ecuadorian Immigration to Italy. International Migration, v. 49 n. 3, 2011, p. 76-98.

CALDERÓN, Leticia (ed.). Votar en la Distancia: La Extensión de derechos políticos a migrantes, experiencias comparadas. Mexico, DF: Instituto de Investigaciones Dr. José Ma. Luis Mora, 2003.

CORTÉS, Almudena. The Transnational Governance of Ecuadorian Migration through Co-Development. International Migration, v. 49, n. 3, 2011, p. 30-51.

ESCOBAR, Cristina. Dual citizenship and extraterritorial political rights in Latin America. Latin American Research Review, v. 42, n. 3, 2007, p. 43-65.

GAMLEN, Alan. Diaspora Engagement Policies: What are they, and what Kind of States use them? Working Paper 06-32 COMPAS, University of Oxford, 2006.

GAMLEN, Alan; CUMMING, Michael; VAALER, Paul M.; ROSSOUW, Laura. Explaining the Rise of Diaspora Institutions. IMI Working Papers, n. 78, University of Oxford: International Migration Institute, 2013.

GUARNIZO, Luis Eduardo; PORTES, Alejandro; HALLER, William. Assimilation and Transnationalism: Determinants of Transnational Political Action among Contemporary Immigrants. American Journal of Sociology, v. 108, n. 1, 2003, p. 1211-1248.

LAFLEUR, Jean-Michel. Why do States Enfranchise Citizens Abroad? Comparative Insights from Mexico, Italy and Belgium. Global Networks, v. 11, n. 4, 2011, p. 481-501.

LAFLEUR, Jean-Michel. The Transnational Political Participation of Latin American and Caribbean Migrants Residing in Europe. International Migration, v. 49, n. 3, 2011, p. 1-9. 
LEVITT, Peggy; DE LA DEHESA, Rafael. Transnational Migration and the Redefinition of the State: Variations and Explanations. Ethnic and Racial Studies, v. 26, n. 4, 2003, p. 587-611.

LEVITT, Peggy; GLICK SCHILLER, Nina. Conceptualizing Simultaneity: A Transnational Social Field Perspective on Society. International Migration Review, v. 38, n. 3, 2004, p. 1002-1039.

MEDINA, Carlos; POSSO, Camilo G. Colombian and South American Immigrants in the United States of America: Education Levels, Job Qualifications and the Decision of Go Back Home. Borradores de Economía, n. 572, 2009.

MEjÍA, William. Colombia y Las Migraciones Internacionales. Evolución Reciente y Panorama Actual a partir de las Cifras. REMHU, Revista Interdisciplinar da Mobilidade Humana, v. 20, n. 39, 2012, p. 185-210.

OSTERGAARD-NIELSEN, Eva. The Politics of Migrants' Transnational Political Practices. International Migration Review, v. 37, n. 3, 2003, p. 760-786.

PADILLA, Beatriz. Engagement Policies and Practices: Expanding the Citizenship of the Brazilian Diaspora. International Migration, v. 49 n. 3, 2011, p. 10-27.

PADILLA, Beatriz; ORTíZ, Alejandra. Ciudadanía Transnacional de Latinoamericanos en Portugal: Considerando el País de Origen Y De Destino. Revista de Estudos e Pesquisas Sobre las Américas, v. 6, n. 1, 2012, p. 1-18.

PORTES, Alejandro; ESCOBAR, Cristina; WALTON RADFORD, Alexandria. Immigrant Transnational Organizations and Development: A Comparative Study. International Migration Review, v. 41 n. 1, 2007, p. 242-281.

PORTES, Alejandro; HALLER, William; GUARNIZO, Luis Eduardo. Transnational Entrepreneurs: An Alternative Form of Immigrant Adaptation. American Sociological Review, v. 67, n. 2, 2002, p. 278-298.

SMITH, Robert C. Diasporic Memberships in Historical Perspective: Comparative Insights from the Mexican, Italian and Polish Cases. International Migration Review, v. 37, n. 3,2003 , p. 724-759.

\section{Resumo}

\section{Políticas de engajamento a favor do transnacionalismo: a expansão da cidadania transnacional entre emigrantes colombianos}

Comunidades de emigrantes que moram no exterior têm atraído o interesse dos países emissores, que têm prestado mais atenção a como os emigrantes interagem com seus países de origem e aos potenciais benefícios dessa interação. Ao focar no caso da Colômbia e ao analisar as iniciativas do programa Colombia Nos Une, este artigo examina o papel que a proatividade de atores institucionais tem no engajamento potencial de migrantes com seus países de origem e na criação de uma cidadania transnacional. A Colômbia, como país emissor, tem buscado aproveitar o capital econômico e humano dos seus emigrantes para aprimorar o seu desenvolvimento, por meio de redes de conhecimento, empreendedorismo e iniciativa sociocultural. Um maior conhecimento de como as políticas 
de origem são implementadas e do impacto que elas têm nas vidas dos migrantes dará uma visão mais abrangente, para entender os efeitos de uma vida transnacional e conceituar a cidadania transnacional.

Palavras-chave: políticas de engajamento, Colômbia, emigração, cidadania, transnacionalismo.

Received for publication in January, $19^{\text {th }}, 2015$

Accepted for publication in July, $02^{\text {nd }}, 2015$

Recebido para publicação em 19/01/2015

Aceito para publicação em 02/07/2015

ISSN impresso: 1980-8585

ISSN eletrônico: 2237-9843

http://dx.doi.org/10.1590/1980-85852503880004515 